\title{
PROFIL APOS SISWA SMP DALAM MENYELESAIKAN SOAL FUNGSI LINEAR DAN GRAFIKNYA
}

\author{
Findrianti Palias ${ }^{1}$, Helti Lygia Mampouw ${ }^{2}$ \\ ${ }^{1,2}$ Universitas Kristen Satya Wacana, Jalan Diponegoro No.52-60 Salatiga \\ 202016032@student.uksw.edu
}

\begin{abstract}
APOS is the crucial stages to describe development of students thinking. The purpose of this research is to describe APOS profiles of middle school students in solving questions of linear function and graph in terms of descriptive qualitative. The main instrument is the researcher with mathematical ability test questions and interview guidelines. The subjects are IX grade of three middle school students with different mathematical ability: high, medium and low. The results showed that at action stage, the subjects had different fluency in explaining the meaning of questions verbally. The high subject was really fluent and fast in mastering the problem and speaking systematically. Otherwise mediun and low subjects still had problem. At process stage, the high and medium subjects is seen through a presentation of mathematical problem solving and clarification of objects to achieve the requirements or not to form the concept by determining functions of domain and range. At object stage, the high and medium subjects implemented the concept and procedures between domain and range by connecting dots of cartesian diagram became lines on graph. At scheme stage, only the high subject was able to achieve, develop the concept and find the formula function through trial and error.
\end{abstract}

Keywords: APOS, linear function, mathematical ability.

\begin{abstract}
Abstrak
Aksi, proses, objek dan skema adalah tahapan penting untuk mendeskripsikan perkembangan berpikir siswa. Penelitian ini bertujuan untuk mendeskripsikan profil aksi, proses, objek dan skema siswa SMP dalam menyelesaikan soal fungsi linear dan grafiknya. Jenis penelitian ini adalah deskriptif kualitatif. Peneliti adalah instrumen utama yang dibantu oleh soal tes kemampuan matematika dan pedoman wawancara. Subjek terdiri dari 3 siswa kelas IX SMP masing-masing 1 berkemampuan matematika tinggi, sedang dan rendah. Hasil penelitian menunjukkan pada tahap aksi, ketiga subjek memiliki perbedaan kefasihan menjelaskan secara verbal maksud dari soal. Subjek berkemampuan matematika tinggi sangat fasih yang ditunjukkan dengan menguasai persoalan, cepat dalam bertutur dan menyampaikannya secara sistematis sedangkan 2 subjek lainnya yang mengalami masalah dalam menguasai persoalan. Tahap proses subjek berkemampuan matematika tinggi dan sedang terlihat pada penyajian situasi matematika yang berkaitan dengan permasalahan serta mengklasifikasi objek-objek berdasarkan dipenuhi atau tidaknya persyaratan yang membentuk konsep tersebut, dengan menentukan domain dan range fungsi. Tahap objek subjek berkemampuan matematika tinggi dan sedang menerapkan konsep dan prosedur antara domain dan range dengan menghubungkan titik-titik pada diagram kartesius dan menjadikannya garis pada grafik. Hanya subjek berkemampuan matematika tinggi yang mampu mencapai skema, mengembangkan konsep yang telah dipelajari dan menemukan rumus fungsi dengan cara coba-coba.
\end{abstract}

Kata Kunci: APOS, fungsi linear, kemampuan matematika.

\section{PENDAHULUAN}

Fungsi linear dan grafiknya adalah materi awal tentang fungsi dan grafik fungsi. Materi fungsi linear di SMP berlanjut ke materi sistem persamaan linear 2 variabel yang diperluas menjadi 3 variabel atau $n$ variabel di SMA. Dari sisi fungsi, materi lanjutan setelah fungsi linear adalah fungsi kuadrat. Di SMA, selain fungsi kuadrat terdapat juga fungsi polinom, fungsi eksponen, fungsi logaritma, fungsi rasional dan fungsi trigonometri. Pemahaman yang baik tentang materi awal dapat menjadi modal awal yang baik untuk mempelajari materi-materi fungsi berikutnya (Purnama Putri et al., 2014).

Pemahaman konsep menjadi sentral dalam menyelesaikan masalah matematika. Kemampuan menyelesaikan masalah dalam matematika adalah kemampuan yang akan digunakan selama hidup 
Profil APOS Siswa SMP dalam Menyelesaikan Soal Fungsi Linear dan Grafiknya, Findrianti Palias, Helti Lygia Mampouw

dan pengetahuan yang baik tentang matematika dapat membantu mempermudah pekerjaan seseorang dalam kesehariannya (Zakaria, 2007). Konsep dikatakan sebagai ide-ide abstrak yang bisa digunakan untuk menggolongkan sekumpulan objek (Depdiknas, 2003) dan menurut Ruseffendi matematika terbentuk sebagai hasil pemikiran manusia berhubungan dengan ide, proses, dan penalaran (Rusefendi, 2006).

Terdapat beberapa kompetensi dasar yang harus dicapai siswa dalam pembelajaran materi fungsi dan grafiknya. Salah satunya adalah siswa mampu mendeskripsikan dan menyatakan relasi dan fungsi dengan berbagai representasi (kata-kata, tabel, grafik, diagram dan persamaan). Pencapaian pembelajaran dilihat dari siswa mampu mengkomunikasikan gagasan matematika dengan jelas, siswa mampu mengenal bentuk aljabar sederhana (linear dan kuadrat) dan memahami konsep fungsi dan menyajikannya (diagram, tabel dan grafik) (Permendikbud, 2016).

\section{Tabel 1.}

Capaian nilai rata-rata hasil UN tahun ajaran 2018/2019

\begin{tabular}{|l|l|c|c|c|}
\hline No & Materi yang diuji & Nasional & $\begin{array}{c}\text { Provinsi } \\
\text { Jawa Tengah }\end{array}$ & $\begin{array}{c}\text { Kota } \\
\text { Salatiga }\end{array}$ \\
\hline 1 & Bilangan & $39,71 \%$ & $43,64 \%$ & $60,12 \%$ \\
\hline 2 & Aljabar & $51,24 \%$ & $54,96 \%$ & $69,95 \%$ \\
\hline 3 & Geometri dan pengukuran & $42,27 \%$ & $45,23 \%$ & $59,51 \%$ \\
\hline 4 & Statistika dan peluang & $55,60 \%$ & $60,85 \%$ & $74,20 \%$ \\
\hline
\end{tabular}

sumber : https://hasilun.puspendik.kemdikbud.go.id)

Laporan hasil ujian nasional SMP tahun ajaran 2018/2019 mata pelajaran matematika secara nasional masih rendah. Hasil belajar siswa masih rendah ditunjukkan dengan nilai yang rata-rata lebih rendah dari KKM dikarenakan siswa kesulitan memahami materi pelajaran (Kusrini, 2018). Tabel 1 menampilkan perbandingan capaian nilai rata-rata mata pelajaran matematika di tingkat nasional, provinsi Jawa Tengah dan kota Salatiga. Baik tingkat nasional maupun provinsi Jawa Tengah, terdapat kecenderungan capaian nilai rata-rata yang rendah. Hal ini berbeda dengan hasil dari kota Salatiga di mana semua capaian melebihi nilai 55\% dan melampaui tingkat nasional maupun provinsi Jawa Tengah. Oleh karena itu sangat menarik untuk meneliti skema berpikir dari siswa di kota Salatiga.

Tabel 2.

Daya serap materi aljabar hasil UN tahun ajaran 2018/2019

\begin{tabular}{|c|l|c|c|c|}
\hline No & Indikator Materi yang diuji & Nasional & $\begin{array}{c}\text { Provinsi Jawa } \\
\text { Tengah }\end{array}$ & Kota Salatiga \\
\hline 1. & Menentukan nilai bentuk aljabar & $55,09 \%$ & $59,83 \%$ & $77,07 \%$ \\
\hline 2. & $\begin{array}{l}\text { Menentukan komplemen dari irisan dua } \\
\text { himpunan }\end{array}$ & $28,84 \%$ & $29,24 \%$ & $44,42 \%$ \\
\hline 3. & $\begin{array}{l}\text { Menentukan rumus fungsi atau daerah } \\
\text { hasil suatu relasi }\end{array}$ & $86,06 \%$ & $89,15 \%$ & $94,02 \%$ \\
\hline 4. & Menentukan nilai variabel dari sistem & $34,40 \%$ & $33,53 \%$ & $51,58 \%$ \\
\hline
\end{tabular}




\begin{tabular}{|c|l|c|c|c|}
\hline & persamaan linier dua variabel & & & \\
\hline 5. & $\begin{array}{l}\text { Menyelesaikan soal persamaan linier } \\
\text { satu variabel }\end{array}$ & $34,20 \%$ & $35,12 \%$ & $51,58 \%$ \\
\hline 6. & $\begin{array}{l}\text { Menyelesaikan masalah operasi } \\
\text { irisan/gabungan himpunan dengan } \\
\text { diagram venn }\end{array}$ & $59,46 \%$ & $69,70 \%$ & $87,13 \%$ \\
\hline 7. & Menyelesaikan soal tentang nilai fungsi & $40,74 \%$ & $44,76 \%$ & $62,35 \%$ \\
\hline 8. & $\begin{array}{l}\text { Menyelesaikan masalah persamaan linier } \\
\text { dua variabel }\end{array}$ & $85,47 \%$ & $91,80 \%$ & $97,20 \%$ \\
\hline 9. & $\begin{array}{l}\text { Menganalisis masalah tentang } \\
\text { persamaan linier dua variabel }\end{array}$ & $36,90 \%$ & $41,54 \%$ & $63,90 \%$ \\
\hline
\end{tabular}

sumber : https://hasilun.puspendik.kemdikbud.go.id

Tabel 2 menunjukkan daya serap berdasarkan indikator-indikator aljabar yang diuji pada ujian nasional SMP tahun ajaran 2018/2019. Indikator menyelesaikan soal tentang nilai fungsi memiliki daya serap yang kurang dari 55\% secara nasional dan provinsi Jawa Tengah, namun capaian di kota Salatiga menunjukkan hasil yang jauh lebih baik. Di sisi lain, terdapat 5 indikator yang hasilnya melampaui capaian indikator menyelesaikan soal tentang nilai fungsi dan 3 indikator yang nilainya lebih rendah. Dengan melihat perbandingan secara nasional, provinsi dan kota, maka menarik untuk meneliti lebih jauh pada materi tentang fungsi, terutama pemahaman materi fungsi dan grafik fungsi oleh siswa SMP di Salatiga.

Materi fungsi dan grafiknya pada kurikulum 2013 diajarkan di kelas VIII semester ganjil. Menurut Callaghan bahwa konsep fungsi adalah suatu konsep yang penting dalam kurikulum matematika juga dipandang konsep dasar penting dalam matematika (Nalole, 2007). Namun, yang terjadi di lapangan dalam pembelajaran masih sering terjadi adanya kesalahan siswa menjawab soal fungsi dan grafik fungsi dikarenakan siswa kurang memahami tahapan dan prosedur tentang materi fungsi tersebut. Banyak siswa yang mengalami kesulitan dan kesalahan dalam mengerjakan soal-soal relasi dan fungsi, dikarenakan pemahaman yang rendah terhadap materi matematika (Sarnawiah \& Yensy, 2019). Pemahaman yang rendah menjadi masalah yang akan berdampak pada penguasaan materi matematika selanjutnya, dikarenakan matematika merupakan mata pelajaran yang berkesinambungan. Terdapat 3 aspek kesulitan siswa dalam menyelesaikan masalah fungsi khususnya pokok bahasan menentukan bentuk fungsi dan grafik fungsi yaitu kesulitan siswa dalam menghitung meliputi kesulitan siswa menyelesaikan operasi perhitungan dengan jawaban yang kurang tepat, kesulitan siswa menafsirkan simbol meliputi kesulitan siswa dalam memahami simbol dan siswa kurang mencermati apa yang ditanyakan dalam soal dan kesulitan siswa memahami materi meliputi kurangnya pemahaman siswa terhadap materi fungsi khususnya pokok bahasan grafik fungsi (Narulita, 2016). Siswa juga memiliki cara berpikir yang beragam dalam menyelesaikan masalah (Wulandari, 2006).

Cara berpikir siswa yang beragam dan pemahaman siswa dapat diketahui dengan menggunakan teori APOS (Action, Prosesses, Object, and Scheme). Teori APOS adalah alat yang digunakan untuk 
Profil APOS Siswa SMP dalam Menyelesaikan Soal Fungsi Linear dan Grafiknya, Findrianti Palias, Helti Lygia

mendeskripsikan skema seseorang terhadap topik matematika. Teori APOS sendiri diperkenalkan oleh Dubinsky. Pada dasarnya teori APOS menganut paham kontruktivisme, terlebih pada kontruktivisme yang dikembangkan oleh Vygotsky, yang dikenal dengan konstruktivisme sosial. Menurut Dubinsky teori APOS menjelaskan bagaimana kegiatan mental anak dalam bentuk aksi, proses, objek, dan skema saat mengkonstruksi konsep dalam matematika (Tall, 1999). Teori APOS mengasumsikan bahwa pengetahuan matematika yang dimiliki oleh seseorang merupakan hasil interaksi dengan orang lain dan hasil konstruksi-konstruksi mental orang tersebut dalam memahami ide-ide matematika. Asiala menyatakan yang menjadi tujuan dari teori APOS adalah konstruksi mental dari siswa (Asiala et al, 2004). Zazkis \& Campbell menyatakan bahwa kerangka teori APOS telah digunakan untuk menganalisis perkembangan berpikir siswa dalam mempelajari topik fungsi dan grup serta topik-topik matematika diskrit (Zazkis \& Campbell, 1996).

Materi fungsi dan grafik fungsi menjadi pijakan untuk mempelajari fungsi dan grafik fungsi lebih lanjut. Oleh karena itu perlu ditelusuri cara siswa membangun skema berpikir, di mana tahapan skema dicapai melalui APOS. Tujuan penelitian ini untuk mengidentifikasi profil APOS siswa SMP dalam menyelesaikan soal fungsi linear dan grafiknya berdasarkan perbedaan kemampuan matematika.

\section{METODE}

Jenis penelitian yang dilakukan oleh peneliti adalah penelitian deskriptif kualitatif. Penelitian deskriptif kualitatif adalah suatu metode yang digunakan untuk meneliti status sekelompok manusia, suatu objek, suatu set kondisi, suatu sistem pemikiran, ataupun suatu kelas peristiwa pada masa sekarang (Nazir, 2011) dan suatu metode penelitian yang digunakan untuk meneliti kondisi objek yang alamiah dimana peneliti sebagai instrumen kunci, pengambilan sampel dilakukan secara purposive, teknik pengumpulan data dengan triangulasi, analisis data bersifat induktif/kualitatif, dan hasil penelitian lebih menekankan makna daripada generalisasi (Sugiono, 2008). Penelitian ini termasuk dalam penelitian deskriptif kualitatif karena penyajiannya menggunakan kata-kata atau narasi dan gambar-gambar untuk menganalisis profil APOS siswa atau juga cara berpikir siswa dalam menyelesaikan masalah fungsi dan grafiknya.

Subjek dalam penelitian ini adalah 3 siswa kelas IX SMP Kristen Satya Wacana (LAB) Salatiga masing-masing berkemampuan matematika tinggi, sedang dan rendah yang sudah pernah belajar materi relasi dan fungsi. Subjek dipilih secara purposive berdasarkan hasil Penilaian Akhir Semester (PAS) mata pelajaran matematika tahun ajaran 2018/2019. Ketiga subjek dipilih dari 41 siswa yaitu jumlah siswa dalam 2 kelas. Hasil PAS dari jumlah siswa diurutkan kemudian dibagi menjadi 5 kategori yaitu tinggi (T) sebanyak 9 orang, agak tinggi (AT) sebanyak 8 orang, sedang (S) sebanyak 8 orang, agak rendah (AR) sebanyak 8 orang dan rendah (R) sebanyak 8 orang. Subjek berkemampuan matematika tinggi diambil dari siswa yang nilainya paling tinggi, subjek berkemampuan matematika 
sedang diambil dari siswa yang nilainya paling tengah pada kategori sedang dan subjek berkemampuan matematika rendah diambil dari siswa yang nilainya paling rendah. Ketiga subjek juga merupakan siswa yang direkomendasikan oleh guru mata pelajaran matematika. Subjek berkemampuan matematika tinggi adalah XD, subjek berkemampuan matematika sedang adalah MW dan subjek berkemampuan matematika rendah adalah SB. Tabel 2 menampilkan karakteristik dari ketiga subjek yang berisi nilai PAS dan kategori kemampuan matematika.

Tabel 3.

Karakteristik Subjek Penelitian

\begin{tabular}{|c|c|c|}
\hline Subjek & Nilai PAS & Kategori \\
\hline XD & 96,00 & Tinggi \\
\hline MW & 53,00 & Sedang \\
\hline SB & 28,00 & Rendah \\
\hline
\end{tabular}

Instrumen penelitian terdiri dari instrumen utama yaitu peneliti itu sendiri dan instrumen bantu yakni tes kemampuan matematika (TKM) dan wawancara. TKM terdiri dari 2 soal mengenai materi fungsi dan grafiknya yang disusun berdasarkan teori APOS. Penelitian ini menggunakan triangulasi waktu yakni terdapat 2 periode dengan selang waktu antara periode 1 dan 2 adalah 1 minggu. Selain TKM berupa soal, peneliti juga melakukan tahapan wawancara. Berikut soal tes kemampuan matematika (TKM) yang diberikan pada subjek :

1. Diketahui fungsi $f(x)=2 x-4$ dengan $\mathrm{P}=\{\mathrm{x} \mid 0 \leq \mathrm{x} \leq 5\}$ variabel $x$ adalah himpunan bilangan cacah ke himpunan bilangan bulat.

a. Tentukanlah daerah asal dan daerah hasil dari fungsi tersebut !

b. Buatlah himpunan pasangan terurutnya dengan menggunakan tabel!

c. Tentukan letak titik-titik pada diagram kartesius!

d. Gambarlah grafik fungsi tersebut !

2. Fungsi $f$ ditentukan oleh $f(x)=a x+b$. Jika nilai dari fungsi itu untuk $f(-3)=-15$ dan untuk $f(3)=9$. Tentukanlah bentuk fungsinya!

Analisis data yang berbentuk interaktif meliputi 3 hal yaitu reduction (reduksi), display (penyajian) dan verification (verifikasi) (Miles dan Huberman, 2009). Pertama adalah reduksi data, pada tahap ini hasil tes tertulis dan wawancara dikategorikan sesuai dengan indikator APOS. Tahap kedua penyajian data yaitu memadankan hasil tes tertulis dan tes wawancara untuk data yang reliabel. Tahap terakhir yaitu verifikasi. Pada tahap ini dilakukan pemeriksaan kembali data yang telah dikumpulkan dan dilakukan pengambilan kesimpulan. 
Profil APOS Siswa SMP dalam Menyelesaikan Soal Fungsi Linear dan Grafiknya, Findrianti Palias, Helti Lygia Mampouw

\section{HASIL}

Hasil tes kemampuan matematika dan wawancara yang telah dilakukan diperoleh informasi terkait dengan profil APOS dari subjek berkemampuan matematika tinggi, sedang dan rendah. Berikut pemaparan hasil penelitian :

\section{Aksi}

Pada tahap aksi subjek harus mampu menjelaskan secara verbal mengenai apa yang diketahui dari soal dan mampu menyajikan situasi matematika yang berkaitan dengan permasalahan pada soal. Ketiga subjek mampu menjelaskan secara verbal tentang soal, hanya saja terdapat perbedaan kefasihan dalam menjelaskan. Subjek berkemampuan matematika tinggi (XD) dalam wawancaranya menjelaskan secara verbal apa saja yang dipahami dari soal, "Eh nomor 1 itu menentukan daerah asal dan daerah hasil dari fungsi yaitu $2 x-4$ lalu membuat himpunan pasangan terurutnya dengan menggunakan tabel yaitu ada $x$, dari fungsi dan juga $x$, y. lalu menggambar titik-titik pada diagram yang sudah ditentukan lalu menggambar grafiknya”. XD juga mampu menyajikan situasi matematika yang terlihat pada gambar 1 .

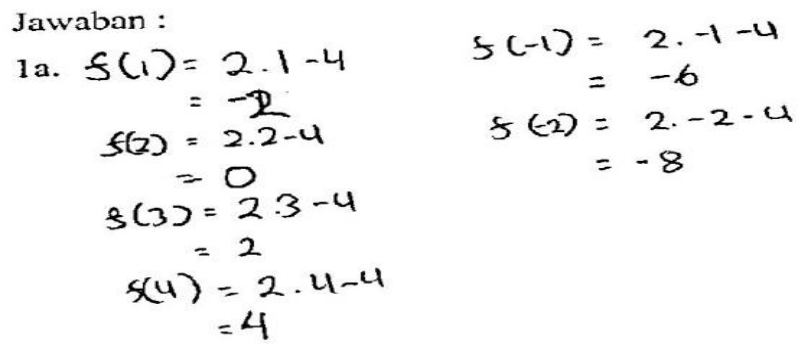

Gambar 1. Aksi dari subjek XD

Subjek berkemampuan matematika rendah (SB) juga mampu menjelaskan secara verbal tentang apa yang diketahui dari soal, namun perlu waktu dalam mengungkapkan apa yang dimaksud dari soal. Seperti yang diungkapkan SB pada awal wawancaranya "gak tau miss maksud soalnya apa, gak ngerti" tetapi ketika diberi waktu untuk membaca kembali, beberapa menit kemudian SB menjelaskan "kayae fungsinya $f(x)=2 x-4$, terus disuruh nyari daerah asal dan daerah hasil" SB juga menjelaskan "aku awalnya cuma nyalin lagi soalnya miss". Gambar 2 menunjukan SB mampu menyajikan situasi matematika terkait dengan soal.

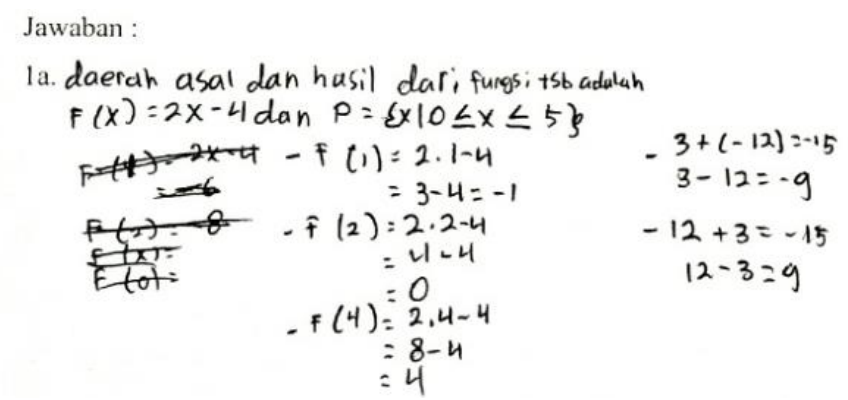

Gambar 2. Aksi dari subjek $S B$ 
Jawaban:

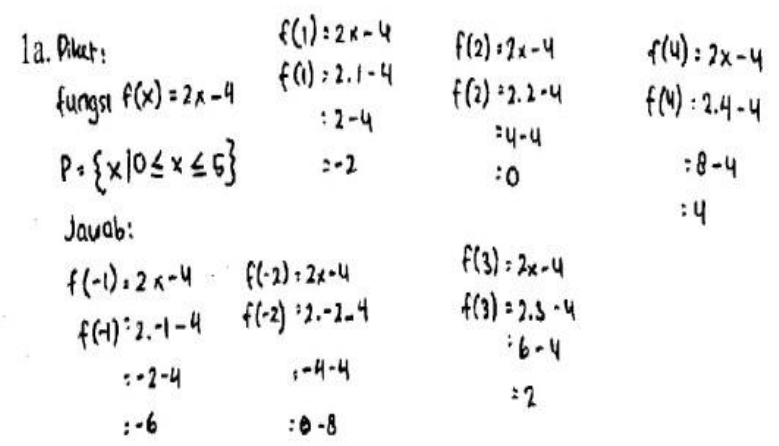

Gambar 3. Aksi dari subjek $M W$

Gambar 3 merupakan aksi dari subjek berkemampuan matematika sedang (MW) yaitu menyajikan situasi matematika dan apa yang diketahui. MW juga mampu menjelaskan secara verbal apa yang diketahui dari soal.

\section{Proses}

Pada tahap proses ini hanya subjek XD dan MW yang bisa yaitu mengklasifikasikan objekobjek berdasarkan dipenuhi atau tidaknya persyaratan yang membentuk konsep tersebut, dengan menentukan domain dan range. XD menjelaskan bagaimana dia memperoleh daerah asal dan daerah hasil "yang pertama saya menurunkan daerah asal 1 caranya dengan menggunakan fungsi yaitu $2 x-4$, 2 dikalikan $x$ yaitu 1 lalu dikurangi 4 sama dengan 3 dikurangi 4 atau -1 , terus $f(2)$ itu 2 dikali 2 minus 4 sama dengan $0, f(3)$ itu 2 dikali 3 minus 4 sama dengan 2 , terus $f(4)$ itu 2 kali 4 minus 4 sama dengan $4, f(-1)$ itu 2 kali -1 minus 4 sama dengan -6 , yang terakhir $f(-2)$ itu 2 dikali -2 minus 4 sama dengan -8 miss". XD juga lanjut menjelaskan "kalo udah dapet hasilnya tinggal masukin dalam tabel pasangan terurutnya miss, bisa langsung hitung hasilnya kalo pake tabel miss gak ribet". Pada tahap ini XD menjawab hanya dalam waktu 5 menit. Hasil wawancara XD juga didukung dengan hasil TKM yang terlihat pada gambar 4 .

b.

\begin{tabular}{|c|c|c|c|c|c|c|}
\hline$x$ & 1 & 2 & 3 & 4 & -1 & -2 \\
\hline $2 x-4$ & -2 & 0 & 2 & 4 & -6 & -8 \\
\hline$(x, y)$ & $(1,-2)$ & $(2,0)$ & $(3,2)$ & $(4,4)$ & $(-1,-6)$ & $(-2,-8)$ \\
\hline
\end{tabular}

Gambar 4. Proses dari subjek XD

b.

\begin{tabular}{|c|c|c|c|c|c|c|}
\hline$x$ & -1 & -2 & 1 & 2 & 3 & 4 \\
\hline $2 x-4$ & -6 & -8 & -2 & 0 & 2 & 4 \\
\hline$(x, y)$ & $(-1,-6)$ & $(-2,-8)$ & $(1,-2)$ & $(2,0)$ & $(3,2)$ & $(4,4)$ \\
\hline
\end{tabular}

Gambar 5. Proses dari subjek $M W$ 
Profil APOS Siswa SMP dalam Menyelesaikan Soal Fungsi Linear dan Grafiknya, Findrianti Palias, Helti Lygia Mampouw

Gambar 5 merupakan tahap proses dari MW. Sama seperti XD dengan memakai tabel untuk menentukan domain dan range. MW dalam wawancaranya menjelaskan bahwa "daerah asalnya itu miss -1, -2, 1, 2, 3, 4 kemudian daerah hasilnya jadi -6, -8, -2, 02 sama 4 miss". Selanjutnya menanggapi pertanyaan tentang bagaimana cara daerah hasil tersebut didapat, MW menjawab dengan “ itu miss dari $f(x)$ itu $x$ nya diganti contohnya yang ketemu -1 dimasukin jadi $f(-1)$ terus dikerjain pake fungsi diganti-ganti miss". Waktu yang dibutuhkan MW untuk menyelesaikan tahap proses ini adalah 11 menit.

\section{Objek}

Pada tahap objek ini subjek mampu menerapkan antar konsep dan prosedural. Subjek mampu menghubungkan antara domain dan range dengan menghubungkan titik-titik pada diagram kartesius menjadi grafik. XD mampu mencapai tahap objek. XD juga memahami materi dengan sangat baik dapat dilihat dalam wawancaranya XD menjelaskan "disumbu $x$ itu daerah asal miss, kalo daerah kawan itu disumbu y. Hasilnya sudah kita dapat tadi langsung aja tentuin titik-titiknya miss". Pernyataan XD tersebut didukung dengan hasil TKM yang dilihat pada gambar 6 yang menunjukkan XD membuat grafik dengan menghubungkan domain dan range menjadi titik pada diagram kartesius dan menjadi grafik.

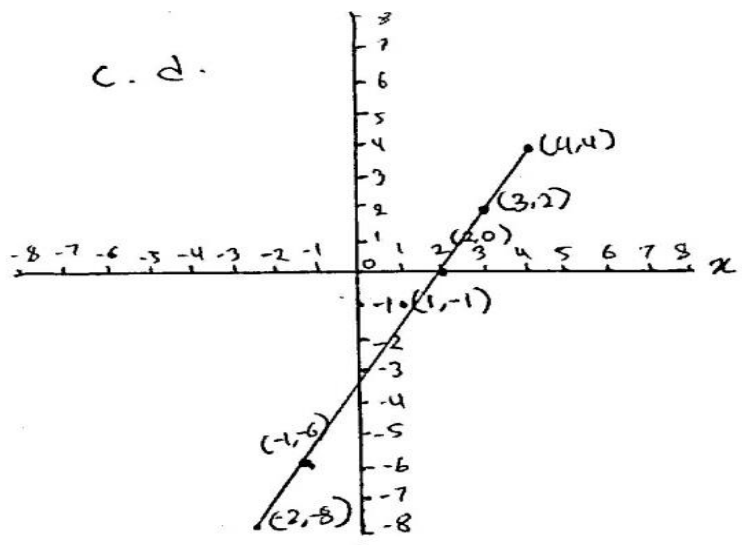

$y$

Gambar 6. Objek dari subjek XD

Subjek MW pada tahap objek ini juga melakukan cara yang sama yaitu menghubungkan domain dan range yang telah didapat dari soal sebelumnya menjadi grafik. Pada tahap ini XD menyelesaikan soal dengan waktu 4 menit dan MW lebih dari 7 menit. Terdapat juga perbedaan pemahaman konsep antara MW dan XD. Dimana XD sangat paham tentang sumbu $x$ merupakan domain dan sumbu $y$ merupakan kodomain, sebaliknya MW tidak mengetahui tentang konsep tersebut. Seperti halnya dinyatakan oleh MW "biasanya ditabel itu miss baris pertama x terus baris kedua itu yang y". Terlihat bahwa MW berpatokkan letak $x$ dan $y$ tergantung baris pada tabel tanpa mengetahui jelas alasannya. Namun begitu MW mampu menyelesaikan tahap objek, terlihat pada gambar 7, MW 
mampu menghubungkan domain dan range menjadi titik-titik kemudian menghubungkannya menjadi grafik.

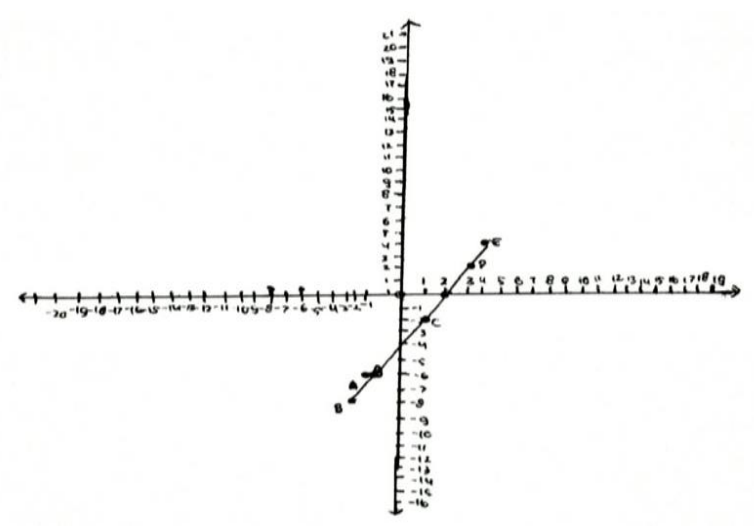

Gambar 7. Objek dari subjek $M W$

\section{Skema}

XD satu-satunya yang mampu mencapai tahap skema. Pada tahap skema ini XD mampu menentukan rumus fungsi $f(x)=a x+b$. XD menjelaskan dengan mencoba satu-satu dan juga tanpa menggunakan rumus kita tetap dapat menemukan nilai $a$ dan $b$. Hal ini dapat diliat dalam wawancaranya "aku biasanya kalo lupa rumusnya pake cara satu-satu miss. Jadi mulai dari 1 sampai 10, a nya dicari dulu, lalu kalo bisa dikurangin berapapun sampe hasilnya -15 miss. Nanti bentuk fungsinya $4 x-3$ miss". Skema dari XD dapat dilihat juga dari hasil TKM pada gambar 7 dan cara mencoba satu-satu yang dilakukan oleh XD dapat dilihat pada gambar 8.

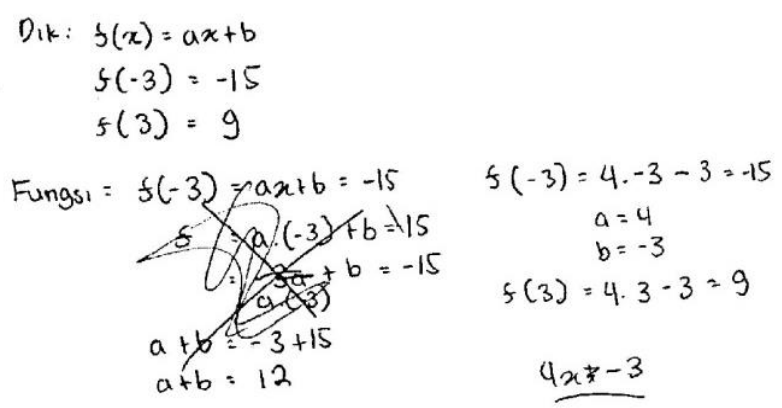

Gambar 7. Skema dari subjek XD

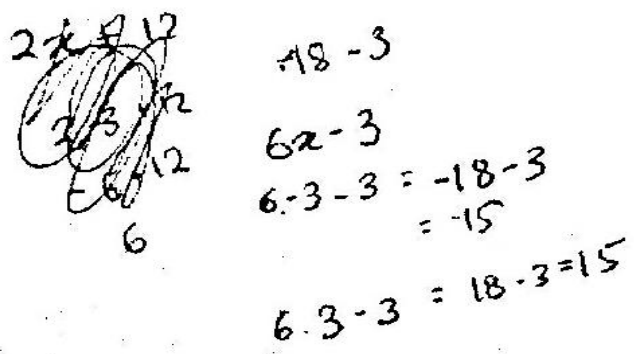

Gambar 8. Coretan subjek XD 
Profil APOS Siswa SMP dalam Menyelesaikan Soal Fungsi Linear dan Grafiknya, Findrianti Palias, Helti Lygia

Hasil penelitian ini adalah ketiga subjek mampu mencapai tahap aksi dengan cara dan tahapan yang sama, namun terdapat perbedaan pada kefasihan dan kecepatan subjek dalam memahami maupun menjelaskan apa yang dimaksud dari soal. Subjek XD aksinya sudah terlihat mulai dari hasil TKM yang diberikan dimana XD mampu menyajikan situasi matematika berdasarkan soal dan juga XD menjelaskan dengan sangat rinci tentang apa yang diketahui dari soal yaitu menentukan daerah asal dan daerah hasil, kemudian membuat himpunan pasangan terurut dengan tabel pasangan terurut, menggambar grafik fungsi dan menentukan bentuk fungsi. Menurut Della dalam hasil penelitiannya terdapat 3 aspek kesulitan siswa dalam memahami materi fungsi, salah satunya kesulitan memahami materi, meliputi kurangnya pemahaman siswa terhadap materi fungsi (Della, 2016). Ini terlihat pada subjek MW dan SB. Kedua subjek mampu menjelaskan secara verbal apa yang dimaksud dari soal, tetapi membutuhkan waktu untuk memahami dan menjelaskan maksud soal dan juga kedua subjek perlu dibimbing secara perlahan untuk dapat mengerti maksud dari soal. Waktu yang dibutuhkan XD, MW dan SB masing-masing adalah 4 menit, 9 menit dan 11 menit.

Tahap proses dan objek menunjukkan ada kesamaan juga perbedaan antara XD dan MW. Kesamaannya yaitu XD dan MW menyelesaikan soal dengan berpatokkan pada tabel pasangan terurut. XD dan MW juga mampu menerapkan antar konsep dan prosedural yaitu menghubungkan titik-titik menjadi grafik fungsi. Perbedaannya terlihat pada pemahaman terhadap konsep materi dan waktu yang dibutuhkan untuk menyelesaikan soal. XD yang mampu dan paham dengan konsep dan mampu menggunakannya untuk menyelesaikan soal dan juga mampu menjelaskan kembali apa yang telah dikerjakan. Pernyataan ini sejalan dengan hasil penelitian Rahmawati yang menyatakan bahwa hanya tingkat pemahaman pada tahap skema yang mampu menghubungkan pengetahuan dari aksi, proses dan objek untuk menyelesaikan masalah dan mampu menjelaskan kembali pengerjaannya (Rahmawati, 2018). Waktu yang dibutuhkan ditahap Proses untuk XD adalah 5 menit dan waktu yang dibutuhkan MW 11 menit. Sedangkan untuk tahap objek, XD memerlukan 4 menit untuk menyelesaikan soal dan MW memerlukan 7 menit.

Dari ketiga subjek hanya terdapat 1 subjek yang mampu mencapai tahapan APOS yaitu subjek berkemampuan matematika tinggi. Hal ini sejalan dengan hasil penelitian Melani yang menyatakan bahwa hanya siswa berkemampuan matematika tinggi yang mampu mencapai APOS (aksi,proses, objek, skema), sebaliknya dengan siswa berkemampuan matematika rendah hanya pada tahap Aksi dan siswa berkemampuan matematika sedang mampu mencapai APO(aksi, proses, objek) (Melani, 2016). XD mampu sampai pada tahap menerapkan konsep secara algoritma dengan baik yaitu dengan mencari satu-satu nilai $a$ dan $b$ tanpa menggunakan rumus fungsi atau tanpa eliminasi maupun substitusi. Waktu yang dibutuhkan XD untuk menyelesaikan soal ditahap skema adalah 7 menit. Total waktu yang dibutuhkan untuk menyelesaikan TKM oleh masing-masing subjek XD, MW dan SB adalah 20 menit, 34 menit dan 45 menit. 
Hasil penelitian ini juga menunjukkan XD dalam menyelesaikan masalah fungsi, tidak melakukan kesalahan apapun. Sebaliknya dengan SB yang melakukan semua jenis kesalahan dan MW yang melakukan kesalahan konsep dalam menjelaskan sumbu $x$ dan sumbu $y$. Hal ini sejalan dengan hasil penelitian yang dilakukan Kamariah yang menjelaskan subjek berkemampuan matematika tinggi tidak melakukan kesalahan dalam penyelesaian soal, subjek berkemampuan matematika sedang melakukan kesalahan konsep dan subjek berkemampuan matematika rendah melakukan semua jenis kesalahan dalam penyelesaian soal (Kamariah \& Marlissa, 2016).

\section{KESIMPULAN}

Hasil penelitian ini menunjukkan bahwa subjek berkemampuan matematika tinggi mampu mencapai skema karena memiliki kemampuan matematika tinggi dan pemahaman konsepnya yang matang, subjek berkemampuan matematika sedang mampu mencapai tahap objek, namun masih membuat kesalahan pemahaman konsep tentang fungsi. Subjek berkemampuan matematika rendah hanya mampu mencapai tahap aksi. Pemahaman materi yang dimiliki subjek berkemampuan matematika rendah sangat minim sehingga sangat berpengaruh pada hasil TKM yang dikerjakan. Seperti halnya materi matematika yang saling terkait satu dengan yang lain, begitupun dengan materi fungsi dan grafiknya, siswa harus paham konsep dasar tentang materi tersebut. Hasil penelitian menggunakan Teori APOS ini juga menunjukkan kemampuan matematika sangat berpengaruh terhadap pemahaman konsep siswa dalam pembelajaran matematika. Dilihat dari bagaimana Subjek berkemampuan matematika tinggi sangat matang dengan konsep materi dan sebaliknya dengan subjek berkemampuan matematika rendah. Pengembangan kualitas pembelajaran yang baik bagi siswa yaitu dalam pembelajaran harus mengutamakan pemahaman konsep juga lebih memperhatikan siswa berkemampuan rendah dan sangat tidak direkomendasikan untuk pengajar melakukan pembelajaran dengan cepat karena akan berdampak pada materi-materi lanjutan lainnya.

\section{DAFTAR PUSTAKA}

Asiala, dkk. (1997). The Development of students, graphical understanding of the derivative (pp. 399431). Journal of Mathematic Behavior.

Depdiknas. (2003). Pedoman khusus pengembangan sistem penilaian berbasis kompetensi smp. Jakarta: Depdiknas.

Dubinsky, E., \& Michael A. M. (2001). APOS: A constructivi theory of learning in undergraduate $\begin{array}{lccc}\text { mathematics } & \text { education } & \text { research. } \\ \text { http://www.math.kent.edu/ edd/publications. html\#C.\%29\%20Mathemati }\end{array}$

Kamariah, \& Marlissa, I. (2016). An error analysis in relation and function tes solving in class vii smp negeri buti merauke. Magistra, 3(1), 30-42.

Kesumawati, N. (2010). Peningkatan kemampuan pemahaman, pemecahan masalah, dan disposisi matematis siswa smp melalui pendekatan pendidikan matematika realistik. Disertasi Doktor UPI.

Kusrini, S. (2018). Upaya Meningkatkan Hasil Belajar Matematika melalui Penggabungan Metode 
Drill dan Demonstrasi Siswa Kelas I-B MIN Wonosari Tahun Pelajaran 2016 / 2017. Jurnal Pendidikan Madrasah, 3(1), 2527-6794.

Melani Khomsah, (2016). Analisis pemahaman siswa materi bangun ruang kelas vii smp berdasarkan teori apos ditinjau dari aktifitas belajar siswa.

Miles dan Huberman. (2009). Qualitative Data Analysis. Jakarta: Universitas Indonesia (UI-Press)

Nalole, M. (2007). Pembelajaran fungsi melalui pemecahan masalah pada mahasiswa semester 1 DII pgsd jurusan pendidikan anak fakultas ilmu pendidikan. Universitas Negeri Gorontalo.

Narulita, Della. (2016). Kesulitan siswa dalam menyelesaikan masalah fungsi. Jurnal Pendidikan Matematika Universitas Muhammadiyah Surakarta.

Nazir, M. (2011). Metode penelitian. Bogor: Penerbit Ghalia Indonesia

Permendikbud. (2016). Standar isi pendidikan dasar dan menengah.

Purnama Putri, A., Nursalam, N., \& Sulasteri, S. (2014). Pengaruh penguasaan materi prasyarat terhadap hasil belajar matematika siswa kelas viii smpn 1 Sinjai Timur. MaPan: Jurnal Matematika Dan Pembelajaran, 2(1), 17-30. https://doi.org/10.24252/mapan.2014v2n1a2

Rahmawati, Suci. (2018). Analisis tingkat pemahaman siswa berdasarkan teori APOS (action, process, object, scheme) pokok bahasan relasi dan fungsi pada siswa kelas vii-A di smp negeri 4 jember. Jember : Universitas Jember.

Ruseffendi, E.T. (2006). Pengantar kepada guru mengembangkan kompetensinya dalam pengajaran matematika untuk meningkatkan CBSA. Bandung: Tarsito.

Sarnawiah, \& Yensy, N. A. (2019). Meningkatkan hasil belajar matematika peserta didik kelas vii-2 smp negeri 3 kota bengkulu melalui model discovery learning ( $D L$ ). Jurnal Pendidikan Matematika Raflesia , 4(2), 47-57. Https://Ejournal.Unib.Ac.Id/Index.Php/Jpmr,

Sugiyono. (2008). Metode penelitian kuantitatif kualitatif dan $r \& d$. Bandung : Alfabet

Tall, D. O. (2001). The Transition to advanced mathematical thinking: functions, limits, infinity, and proof (pp.495-511). New York: Macmillan Publishing Company.

Wulandari, Setiyati Puji, dkk.(2006). Profil pemecahan masalah spldv dengan langkah polya ditinjau dari kecerdasan logis matematis siswa.

Zahorik, John, A. (1995). Constructivist teaching (Fastback 390). Bloomingthon Indiana: Phi-Delta Kappa Educational Foundation.

Zakaria, Effandi (2007). Trend pengajaran dan pembelajaran matematika. Kuala Lumpur: Utusan Publications. 